\title{
PENGEMBANGAN PEMAHAMAN KONSEPTUAL DAN DISPOSISI MATEMATIS SISWA MELALUI PENERAPAN PENDEKATAN PROBLEM SOLVING DI SMA
}

\author{
Nurapni Sopia ${ }^{1}$, Sugiatno ${ }^{2}$, Agung Hartoyo ${ }^{3}$ \\ Pendidikan Matematika, STKIP Persada Khatulistiwa ${ }^{1}$, Universitas Tanjungpura ${ }^{2,3}$ \\ e-mail: $\underline{{ }^{1} \text { nurapni22sopia @gmail.com }}$
}

\begin{abstract}
This study aims to uncover and analyze: (1) a conceptual understanding of mathematical students in learning with problem solving approach, (2) differences in conceptual understanding of mathematical between students' level of ability of upper, middle and lower gain mathematics learning with problem solving approach, (3) mathematical dispositions of students in learning with problem solving approach, and (4) the contribution of problem solving approach to the development of conceptual understanding and the ability of students' mathematical disposition. The objectives are achieved through the design of one group pretest-posttest. The population in this study were class X SMA Hope in Porcupine District school year 2016/2017 with a sample of 30 people from three classes taken at random. Conceptual understanding of data acquisition through the test and analyzed using parametric test while the data collected through questionnaires mathematical disposition. Based on the analysis concluded that concluded that learning through problem solving approach contributed to the conceptual understanding and students' mathematical disposition.
\end{abstract}

Keyword: Conceptual Understanding, Disposition Mathematically, Problem Solving Approach

\begin{abstract}
Abstrak. Penelitian ini bertujuan untuk mengungkap dan menganalisis: (1) pemahaman konseptual matematis siswa dalam pembelajaran dengan pendekatan problem solving, (2) perbedaan pemahaman konseptual matematis antara siswa tingkat kemampuan atas, menengah dan bawah yang memperoleh pembelajaran matematika dengan pendekatan problem solving, (3) disposisi matematis siswa dalam pembelajaran dengan pendekatan problem solving, dan (4) kontribusi pendekatan problem solving terhadap perkembangan kemampuan pemahaman konseptual dan disposisi matematis siswa.Tujuan tersebut dicapai melalui rancangan one group pretest-posttest. Populasi dalam penelitian ini adalah siswa kelas X SMA Harapan di Kabupaten Landak tahun pelajaran 2016/2017 dengan sampel sebanyak 30 orang dari 3 kelas yang diambil secara acak (random sampling). Perolehan data pemahaman konseptual melalui tes dan dianalisis menggunakan uji parametrik sedangkan data disposisi matematis dikumpulkan melalui angket.Berdasarkan hasil analisis disimpulkan bahwa disimpulkan bahwa pembelajaran melalui pendekatan problem solving berkontribusi terhadap pemahaman konseptual dan disposisi matematis siswa.
\end{abstract}

Kata Kunci: Pemahaman Konseptual, Disposisi Matematis, Pendekatan Problem Solving 


\section{PENDAHULUAN}

Satu di antara tujuan pembelajaran matematika sekolah yang dikemukakan oleh Badan Standar Nasional Pendidikan (BSNP) menyatakan bahwa "agar siswa memiliki kemampuan memahami konsep matematika, menjelaskan keterkaitan antar konsep dan mengaplikasikan konsep atau algoritma secara luwes, akurat, efisien dan tepat dalam pemecahan masalah (BSNP, 2006). Tujuan ini mendeskripsikan bahwa kemampuan memahami konsep merupakan komponen penting dari tujuan pembelajaran matematika sekolah. Pentingnya tujuan ini dalam National Council of Teacher of Mathematics (NCTM) juga dideskripsikan dari standar kecakapan matematis, yaitu pemahaman konseptual merupakan landasan bagi kelancaran prosedural dan problem solving lanjut dalam belajar matematika (NCTM, 2001). Belajar dengan pemahaman juga membuat pembelajaran matematika menjadi lebih mudah. Dengan demikian pemahaman konseptual matematis perlu mendapat perhatian yang khusus dari guru, karena kemampuan tersebut merupakan landasan bagi siswa dalam bermatematika.

$\begin{array}{rlr}\text { Beberapa } & \text { fakta di lapangan } \\ \text { mengindikasikan } & \text { bahwa, } & \text { pemahaman }\end{array}$
konseptual matematis kurang dimiliki siswa. Hasil penelitian yang dilakukan oleh Setoto, dkk (2013) mengenai kesalahan dan penyebab pada siswa kelas X SMA Negeri 1 Kendal Tahun Pelajaran 2011/2012 dalam menyelesaikan soal materi jarak pada bangun ruang dengan menggunakan prosedur Newman. Diperoleh dari enam subjek penelitian, semua subjek dapat melewati langkah membaca tanpa adanya kesalahan. Terdapat empat anak atau $66,67 \%$ melakukan jenis kesalahan memahami masalah. Penyebabnya berkaitan dengan ilustrasi yang mereka buat. Kemudian tiga dari enam anak atau $50 \%$ melakukan jenis kesalahan kemampuan memproses dan penulisan jawaban. Selain itu berdasarkan hasil studi yang dilakukan oleh Kurniasari (2013) terhadap 70 orang siswa, tentang identifikasi kesalahan siswa dalam menyelesaikan soal geometri materi dimensi tiga kelas XI IPA SMA diperoleh berdasarkan: (1) kesalahan abstraksi yang dilakukan siswa meliputi: 55 orang siswa salah mengabstraksikan penentuan jarak pada bidang dan 50 orang siswa salah dalam menentukan sudut antara garis dan bidang;(2) kesalahan prosedural yang dilakukan siswa meliputi: 48 orang siswa salah pada perhitungan bentuk akar dan 25 orang siswa salah dalam menggunakan rumus;(3) kesalahan konsep yang dilakukan siswa meliputi: 40 orang siswa salah pada konsep jarak dan 25 orang siswa salah pada konsep sudut.

Peneliti juga memperoleh hasil dari prariset yang diberikan kepada siswa kelas $X$ SMA Harapan Pahauman yang terdiri atas tiga kelas dengan total jumlah siswa 107 orang terdeskripsi kekurangannya sebagai berikut: (1) $83,33 \%$ siswa kurang memahami konsep jarak titik ke titik, titik ke garis, dan titik ke bidang; (2) $94,50 \%$ siswa keliru dalam perhitungan bentuk akar; (3) $75,65 \%$ siswa keliru dalam menggunakan rumus. Berikut 
hasil satu di antara siswa yang mengikuti prariset.

\section{Sebagaimana}

dikemukakan

Ruseffendi (2006), bahwa terdapat banyak peserta didik yang setelah belajar matematika, tidak mampu memahami bahkan pada bagian yang paling sederhana sekalipun, banyak konsep yang dipahami secara keliru sehingga matematika dianggap sebagai ilmu yang sukar, ruwet dan sulit. Hal tersebut mengakibatkan siswa yang memiliki kemampuan atas, menengah dan bawah mempunyai mindset bahwa matematika itu sulit untuk dipahami. Apabila kondisi demikian terus berlanjut, maka akan berdampak buruk terhadap kualitas pembelajaran siswa dalam memahami materi matematika berikutnya. Agar siswa berhasil dalam bidang matematika, maka perlu memiliki kemampuan pemahaman konseptual dan juga harus memiliki sikap yang positif terhadap matematika. Hudiono (2006) juga menyatakan bahwa pandangan konstruktivisme dalam pembelajaran matematika, sasaran utamanya adalah mengharapkan munculnya kemampuan siswa dalam masalah matematika dengan pemahaman yang dimiliki, siswa harus aktif membangun pengetahuannya berdasarkan kemampuan intelektual yang dimilikinya satu diantaranya yaitu kemampuan awal matematika.

Suatu konsep mudah dipahami dan diingat oleh siswa bila konsep tersebut disampaikan melalui prosedur dan langkahlangkah yang tepat, jelas dan menarik. Pada kenyataannya penyampaian konsep dalam pembelajaran matematika diberikan dengan cara menghafal sehingga siswa cenderung terhambat memahaminya. Berdasarkan hasil wawancara terhadap seorang guru matematika kelas X SMA Harapan Pahauman terungkap bahwa pendekatan yang digunakan dalam menyampaikan materi matematika cenderung dengan ekspositori. Kecenderungan ini mengikuti langkah mengajar: pertama, kegiatan pendahuluan terdiri dari 3 bagian yaitu apersepsi, motivasi, dan menyampaikan tujuan pembelajaran. Pada bagian ini kegiatan membahas PR dengan guru selalu menawarkan atau menunjuk siswa untuk mengerjakan di papan tulis, kemudian guru memeriksa dan mengoreksi hasil pekerjaan siswa. Kedua, pada kegiatan inti, guru cenderung menggunakan ekpositori, diskusi dan tanya jawab. Guru dalam menyampaikan materi lebih banyak langsung mengaplikasikan suatu konsep ke dalam contoh soal yang ada di dalam buku pegangan yakni buku pelajaran matematika kelas X yang ditulis oleh Yustinu Suhardi yang juga dimiliki oleh siswa. Soal latihan dan PR banyak diambil dari buku pegangan tersebut. Guru lebih banyak mendominasi kegiatan belajar mengajar. Ketiga, pada kegiatan penutup, guru tidak pernah mengajak siswa untuk menyimpulkan materi yang telah dipelajari pada setiap pertemuan. Kegiatan penutup biasanya hanya dengan memberikan PR.

Dari uraian tersebut terlihat pembelajaran cenderung berpusat pada guru menekankan proses prosedural, tugas latihan yang mekanistik dan kurang memberi peluang 
kepada siswa guna mengembangkan pemahaman konseptual serta menggali pengetahuan akan pemahaman konsep yang telah diketahui dan dengan adanya otoritas dari guru yang terkesan hanya memberi tahu sehingga siswa terlihat menerima apa adanya. Hal ini terindikasi ketika siswa diberikan permasalahan berupa soal-soal non rutin, siswa enggan untuk mengerjakannya bahkan ia menyerah terlebih dahulu sebelum mencoba menyelesaikan soal tersebut. Siswa kurang termotivasi untuk belajar, perhatian siswa terhadap hasil belajar atau nilai yang diperoleh siswa cenderung pasrah, bahkan saat mendapatkan nilai di bawah kriteria ketuntasan minimal pun siswa tersebut tidak mau untuk melakukan perbaikan. Senada dengan pernyataan dikemukakan oleh Syaban (2009) "Pada saat ini, daya dan disposisi matematis siswa belum tercapai sepenuhnya".

Hal tersebut mendeskripsikan belum terwujudnya sikap positif siswa terhadap matematika dan rasa percaya diri serta keingintahuan siswa terhadap pemahaman akan konsep-konsep yang telah diajarkan sehingga untuk mengkaitkan hubungan antar konsep sukar dipahami oleh siswa pada akhirnya berdampak pada kurang ketercapaian tujuan pembelajaran matematika, yakni memiliki sikap menghargai kegunaan matematika dalam kehidupan, yaitu memiliki rasa ingin tahu, perhatian dan minat dalam mempelajari matematika, seperti sikap ulet dan percaya diri dalam pemecahan masalah (BSNP, 2006). Disposisi matematis siswa tidak akan tumbuh dan berkembang dalam lingkungan pembelajaran yang dikondisikan agar siswa hanya duduk dengan manis untuk mendengar dan menerima informasi dari guru.

Disposisi matematis harus ditingkatkan karena merupakan faktor utama menentukan kesuksesan belajar (Kilpatrick, $\mathrm{dkk}, 2001)$. Temuan penelitian ini diperkuat oleh pendapat Killpatrik, dkk (2001) bahwa beberapa kemampuan menentukan kesuksesan siswa dalam mempelajari matematika, diantaranya pemahaman konsep, kompetensi strategis, penalaran adaptif, kelancaran prosedural dan sikap produktif. Disposisi matematis siswa berkembang ketika mereka mempelajari aspek kompetensi lainnya. Semakin banyak konsep dipahami oleh seorang siswa, siswa tersebut semakin yakin bahwa matematika itu dapat dikuasai.

Dapat dipahami bahwa disposisi matematis sangat menunjang keberhasilan belajar matematika. Siswa memerlukan disposisi matematis untuk bertahan dalam menghadapi masalah, mengambil tanggung jawab dalam belajar dan mengembangkan kebiasaan kerja baik dalam matematika. Karakteristik demikian penting dimiliki siswa. Kelak, siswa belum tentu akan menggunakan semua materi yang mereka pelajari, tetapi dapat dipastikan bahwa mereka memerlukan disposisi positif untuk menghadapi situasi problematik dalam kehidupan mereka.

Oleh karena itu, guru hendaknya memberikan kesempatan luas dalam mengembangkan pemahaman konseptual dan disposisi matematis siswa, guru harus mampu memberikan pengalaman belajar matematik yang baik dengan cara melatih siswa untuk menyelesaikan masalah matematika terkait 
pemahaman konseptual. Di samping itu, perlu mendorong dan membantu siswa agar mengerjakan soal-soal matematika dengan tekun, percaya diri, pantang menyerah, dan melakukan refleksi terhadap langkah-langkah penyelesaian soal yang telah dilakukannya, sehingga tumbuh sikap atau disposisi positif terhadap matematika dalam diri siswa. Kegiatan tersebut terkandung dalam suatu pendekatan. Dengan memilih pendekatan pembelajaran yang sesuai yakni pendekatan problem solving.

Pendekatan problem solving adalah suatu cara menyajikan pelajaran dengan mendorong siswa untuk mencari atau memecahkan suatu masalah dalam rangka pencapaian tujuan pengajaran. Problem solving merupakan bagian dari tujuan kurikulum matematika yang sangat penting karena dalam proses pembelajaran maupun penyelesaiannya, siswa dimungkinkan memperoleh pengalaman menggunakan pengetahuan serta keterampilan yang sudah dimiliki untuk diterapkan pada pemecahan masalah. Di negara-negara maju seperti Amerika Serikat dan Jepang kegiatan tersebut merupakan inti dari kegiatan pembelajaran matematika di sekolah. Selain itu, NCTM (2000) juga menyatakan bahwa problem solving diberikan pada awal pembelajaran guna mengetahui apa yang telah diketahui siswa.

Berdasarkan hasil penelitian Fariha (2013), setelah dianalisis dengan melihat NGain kemampuan berpikir kritis matematis yang bernilai positif, yaitu 0,397 untuk kelas kontrol dan 0,544 untuk kelas eksperimen kemudian dilakukan pengujian dan disimpulkan bahwa peningkatan kemampuan berpikir kritis matematis kelas yang diajarkan dengan pendekatan problem solving (kelas eksperimen) lebih tinggi dari kelas yang diajarkan tanpa pendekatan problem solving ditinjau berdasarkan keseluruhan siswa dan berdasarkan pengelompokan siswa. Selain itu, hasil perhitungan effect size dalam penelitian yang dilakukan oleh Whindarti, dkk (2015), terdapat peningkatan disposisi matematis siswa sekitar 49,83\% setelah menerapkan pendekatan problem solving. Berdasarkan uraian yang telah dikemukakan, maka penulis bermaksud melakukan penelitian berjudul "Pengembangan Pemahaman Konseptual dan Disposisi Matematis Siswa melalui Penerapan Pendekatan Problem Solving di Sekolah Menengah Atas" (Studi pada SMA Harapan Pahauman Tahun Pembelajaran 2015/2016”.

Berdasarkan latar belakang masalah yang dikemukakan, maka secara umum masalah dalam penelitian ini adalah "Bagaimana pemahaman konseptual dan disposisi matematis siswa kelas $\mathrm{X}$ melalui penerapan pendekatan problem solving dalam materi jarak dimensi tiga di SMA Harapan Pahauman tahun pelajaran 2015/2016?".

Secara khusus rumusan masalah dalam penelitian ini adalah: (1)bagaimana pemahaman konseptual matematis siswa setelah mendapatkan pembelajaran dengan pendekatan problem solving?, (2)Apakah terdapat perbedaan pemahaman konseptual matematis antara siswa tingkat kemampuan 
atas, menengah dan bawah yang memperoleh pembelajaran matematika dengan pendekatan problem solving?, (3) bagaimana disposisi matematis siswa dalam pembelajaran dengan pendekatan problem solving?, dan (4) seberapa besar kontribusi pendekatan problem solving terhadap perkembangan pemahaman konseptual matematis siswa?.

Adapun tujuan penelitian secara umum penelitian ini bertujuan untuk mengungkap dan menganalisis pemahaman konseptual dan disposisi matematis siswa kelas $\mathrm{X}$ melalui penerapan pendekatan problem solving dalam materi jarak dimensi tiga di SMA Harapan Pahauman tahun pelajaran 2015/2016.

Lebih khusus tujuan penelitian ini adalah:(1)untuk mengungkap dan menganalisis pemahaman konseptual matematis siswa dalam pembelajaran dengan pendekatan problem solving.(2) untuk mengungkap dan menganalisis apakah terdapat perbedaan pemahaman konseptual matematis antara siswa tingkat kemampuan atas, menengah dan bawah yang memperoleh pembelajaran matematika dengan pendekatan problem solving, (3) untuk mengungkap dan menganalisis disposisi matematis siswa dalam pembelajaran dengan pendekatan problem solving, dan (4) untuk mengungkap kontribusi pendekatan problem solving terhadap perkembangan kemampuan pemahaman konseptual dan disposisi matematis siswa.

\section{METODE}

Penelitian ini dilaksanakan di kelas X SMA Harapan di Kabupaten Landak tahun pelajaran
2016/2017. Berdasarkan fokus dan tujuan penelitian yang direncanakan ingin dicapai penelitian ini menggunakan metode eksperimen semu. Tujuan dari metode eksperimen semu adalah untuk mengetahui respons siswa yang dikaji menurut pemahaman konseptual dan disposisi matematis akibat dari pembelajaran matematika dengan pendekatan problem solving.

Adapun desain penelitian yang digunakan dalam rancangan penelitian ini adalah one group prestes-postest. Populasi dalam penelitian ini adalah seluruh siswa kelas $\mathrm{X}$ SMA Harapan Pahauman yang terdiri dari tiga kelas, yaitu kelas XA, XB, dan XC. Oleh karena kemampuan siswa dalam ketiga kelas homogen maka teknik dalam pengambilan sampel menggunakan teknik acak (random sampling)dengan jumlah sampel penelitian adalah 30 orang. Data yang dikumpulkan dalam penelitian ini yakni data pemahaman konseptual melalui tes yang berbentuk uraian kemudian dianalisis menggunakan statistik parametrik jalur dan disposisi matematis siswa dengan angket.

\section{HASIL DAN PEMBAHASAN}

Berdasarkan hasil analisis data pretes dan postes pemahaman konseptual matematis siswa berdasarkan tingkat kemampuan atas, sedang dan bawah tampak mengalami peningkatan ditunjukkan dengan diperolehnya rata-rata skor pada hasil postes lebih tinggi dibandingkan rata-rata skor pretes disetiap aspek yang disajikan dalam tabel 1 dan 2 . 
problem solving mempunyai ciri khas yakni mengawali kegiatan pendahuluan dengan memberikan masalah yang berkaitan dengan kehidupan sehari-hari dan representasi gambar kepada siswa, sehingga siswa terlibat secara aktif dalam memahami konsep dan prinsip dari suatu materi. Pemberian masalah dapat melatih siswa dalam melakukan kebiasaankebiasaan matematis seperti yang diungkap oleh Buchanan (1987) problem matematika sebagai soal non rutin yang membutuhkan lebih dari prosedur atau algoritma yang mudah diperoleh dalam proses penyelesaiannya. Sehingga mempengaruhi pemahaman konseptual matematis siswa tersebut.

Pembelajaran yang diawali dengan pemberian masalah menjadikan siswa tertantang untuk menyelesaikan masalah tersebut sehingga dapat mengundang pertanyaan-pertanyaan dan gagasan serta pendapat yang bervariasi. Hal ini selaras dengan Lampert (Ericson, 1955) yang mengemukakan bahwa alasan penting untuk memilih suatu masalah atau tugas segyogyanya masalah tersebut dapat melibatkan semua siswa dilakukan dalam membuat dan menguji hipotesis matematika.

Faktor lain yang menjadi pendukung pembelajaran dengan pendekatan problem solving dapat terlaksana dengan baik yang mengakibatkan pemahaman konseptual matematis siswa berkembang adalah dengan merancang LKS yang berisi masalah-masalah yang berkaitan dengan kelima aspek dalam pemahaman konseptual matematis dan ada berkaitan dengan problem solving diantaranya yakni memiliki banyak solusi serta lebih dari satu cara penyelesaian. LKS merupakan lembar panduan bagi siswa yang digunakan untuk melakukan kegiatan penyelidikan atau pemecahan masalah (Trianti, 2010). Dalam Dalam proses pembelajaran matematika, LKS dapat difungsikan untuk menemukan konsep, prinsip, juga untuk aplikasi konsep dan prinsip (Nurul, 2011).

Beberapa hal yang harus dimuat dalam LKS yaitu petunjuk siswa mengenai topik yang dibahas, persoalan, waktu yang tersedia untuk mengerjakan, tujuan pembelajaran yang diharapkan diperoleh siswa setelah mereka belajar dengan LKS tersebut serta petunjuk khusus tentang langkah-langkah kegiatan yang diberikan secara terperinci dan diselingi dengan pelaksanaan kegiatan (Prayitno, 2003). LKS yang diberikan membimbing siswa untuk menemukan dan menyelidiki konsep-konsep matematika yang sedang dipelajari sehingga pembelajaran lebih menekankan pada aktivitas siswa, guru hanya sebagai fasilitator dan motivator siswa, dengan kata lain siswalah yang menjadi subjek belajar. Slameto (1995) mengatakan bahwa keaktifan siswa dalam proses pembelajaran merupakan salah satu faktor yang dapat meningkatkan hasil belajar siswa. Sehingga LKS yang digunakan dapat melatih siswa untuk mengembangkan pemahaman konseptual matematis dengan cara berpikir kreatif dan aktif. Hal ini terkandungdalam disposisi matematis yang positif juga sebagai pendukung terjadinya perkembangan pemahaman konseptual.

Siswa yang memiliki pemahaman konseptual yang baik membangun sikap atau disposisi matematis yang positif terhadap 
pembelajaran matematika. Hal ini diperkuat dengan perolehan hasil penelitian yakni skor sikap $(3,19)$ lebih besar dari skor netral $(2,68)$ yang artinya disposisi matematis siswa terhadap pembelajaran melalui pendekatan problem solving pada umumnya berpendapat positif.Disposisi matematis siswa tampak ketika siswa menyelesaikan tugas matematika, dikerjakan dengan percaya diri, tanggung jawab tekun, pantang putus asa, merasa tertantang, memiliki cara lain, dan melakukan refleksi terhadap cara berpikir yang dilakukan. Selain itu juga, siswa yang berusaha mengaitkan konsep matematika yang baru dengan konsep matematika yang sudah dipelajarinya menunjukkan bahwa siswa tersebut mempunyai ketekunan dalam mempelajari matematika. Hasil temuan ini didukung oleh NCTM (2000) yang mengatakan bahwa apabila siswa mampu mengaitkan ide-ide matematika maka pemahaman matematikanya akan semakin dalam dan bertahan lama karena mereka mampu melihat keterkaitan antar topik dalam matematika, dengan konteks selain matematika dan dengan pengalaman hidup sehari-hari.

Siswa yang berusaha mengkoneksikan materi matematika yang baru dengan materi yang telah dipelajari sebelumnya menunjukkan bahwa siswa tersebut memiliki ketekunan yang tinggi, berarti siswa tersebut membangun disposisi yang positif terhadap matematika. Disposisi matematis harus ditingkatkan karena merupakan faktor yang terpenting dalam menentukan kesuksesan belajar siswa (Kilpatrick et.al 2001).

Adanya disposisi yang positif maka kegiatan pembelajaran melalui penerapan pendekatanproblem solving memberikan konstribusi sebesar 50\% terhadap pemahaman konseptual matematis siswa. Hal ini juga didukung rasa keingintahuan atau antusias dari siswa untuk berpartisipasi melalui proses adaptasi dalam kegiatan pembelajaran menggunakan pendekatan yang baru bagi mereka.

\section{SIMPULAN (PENUTUP)}

Berdasarkan hasil temuan tersebut dapat disimpulkan bahwa: (1) kemampuan pemahaman konseptual matematis dalam materi bangun ruang sesudah diberikan pembelajaran menggunakan pendekatan problem solving mengalami peningkatan yang signifikan, (2) pemahaman konseptual matematis kelompok atas dan bawah terdapat perbedaan yang signifikan setelah penerapan pendekatan problem solving, (3) pendekatan problem solving memberikan disposisi matematis yang positif terhadap siswa dalam pembelajaran mengenai materi jarak dalam bangun ruang dimensi tiga, (4) pendekatan problem solving memberikan kontribusi positif sebesar 50\% artinya memberikan pengaruh yang kuat terhadap pemahaman konseptual matematis siswa, ketika memahami materi jarak dalam bangun ruang dimensi tiga.

\section{DAFTAR PUSTAKA}

Badan Standar Nasional Pendidikan (BSNP). 2006. Panduan Penyusun 
KTSP Jenjang Pendidikan Dasar dan Menengah. Jakarta: Depdiknas.

Buchanan, N. 1987. Factors Contributing to Mathematical Problem Solving,Performance:An expeoratory study. Educational Studies in Mathematics.

Fariha, M. 2013. Kemampuan Berpikir Kritis Matematis Dan Kecemasan Matematika Dalam Pembelajaran Dengan Pendekatan Problem Solving(Studi Eksperimen Pada Kelas X Man Rukoh Kota Banda Aceh). Jurnal Peluang. 1(2):43-50.

Hudoyo, H. 2003. Pengembangan Kurikulum dan Pembelajaran Matematika. Malang: Universitas Negeri Malang.

Kilpatrick, J. et.al. 2001. The Standars of Mathematical Proficiency. Adding it up:Helping Children Learn Mathematics. Washington DC:National Academy Press.

Kurniasari, I. 2013. Identifikasi Kesalahan Siswa Dalam Menyelesaikan Soal Geometri Materi Dimensi Tiga Kelas XI IPA SMA. Makalah dipresentasikan dalam Seminar Nasional Matematika dan Pendidikan Matematika. FMIPA:UNY

National Council of Teachers of Mathematics (NCTM). 2001. Adding it Up: Helping Childern Learn Mathematics. Washington, DC: National Academy Press.

National Council of Teachers of Mathematics (NCTM). 2000. Principles and Standards for School Mathematics. Reston. VA: NCTM.

Nurul, H. 2011. Penerapan Model Kooperatif Tipe Teams Assisted
Individualization dalam Pembelajaran Matematika Siswa Kelas VIII SMPN 4 Payakumbuh Tahun Pelajaran 2010/2011. Jurnal Peluang. 1(2):1-3.

Prayitno. 2003. Materi Diklat Pedoman Pemngembangan System Penilaian. Yogyakarta: FMIPA UNY

Ruseffendi, E.T. 2006.Pengantar kepada Membantu Guru Mengembangkan Kompetensinya dalam Pengajaran Matematika untuk Meningkatkan CBSA. Bandung: Tarsito.

Setoto, dkk. 2013. Analisis Kesalahan Hasil Belajar Siswa Dalam Menyelesaikan Soal Dengan Prosedur Newman, Jurusan Matematika, Fmipa, Universitas Negeri Semarang, Indonesia.

Slameto. 1995. Belajar dan Faktor-faktor yang Mempengaruhinya. Jakarta:Rineka Cipta.

Syaban, M. 2009. Menumbuhkembangkan Daya dan Disposisi Matematis Siswa Sekolah Menengah Atas Melalui Pembelajaran Investigas. Jurnal Educationist. 3(2):129-136. 